\title{
Correspondence
}

\section{Rhythm of Rabbit Teeth Cells}

SIR,--Discussing the findings of Dr H. P. Rush (Nature, 226, 406; 1970) that DNA synthesis in the slime mould Physarum polycephalum occurs immediately after mitosis and without an intervening $\mathrm{G}_{1}$ period in the cell cycle, your correspondent suggests that most of the available data of this kind relate either to artificial situations, to slime moulds or to simple unicellular forms such as amoebae.

This is not entirely the case, however. In the proceed. ings of a symposium on naval medicine held at the Royal Society of Medicine in 1965 I reported that in rabbits the pre-ameloblasts (specialized cells concerned with laying down enamel matrix on the continuously growing teeth) have a cell cycle occupying between 19 and $20 \mathrm{~h}$ which was summarized in the following terms:

$$
\begin{aligned}
& \mathrm{G}_{2}+\mathrm{M}+\mathrm{G}_{1}<10 \mathrm{~h} \\
& \mathrm{G}_{2}+\mathrm{M}>9 \mathrm{~h}
\end{aligned}
$$

In other words, the duration of $G_{1}$ is very short, and synthesis must begin almost immediately after mitosis is complete ${ }^{1}$.

Yours faithfully,

MRC Dental Lnit, WiLl Starkey

The Dental School, Lower Maudlin Street, Bristol BS1 2LY.

${ }^{2}$ Starkey, W. E., J. Roy. Nav. Med. Serv., 51, 193 (1965).

\section{Reprint Request Reflexes}

SIR,-When you accepted my letter (Nature, February 14, 1970) you asked mo to let you know the result. Especially as you published a similar letter adjacent to mine, I suspect that I may be taking part in your experiment, which I do most willingly! My experiment was of the "try it and sce" variety. The interim result, for the first period of nearly two months, is as follows.

The most gratifying result to me was receiving a number of appreciative letters from colleagues. So far, there have been twenty-one request cards from USA and Canada and twenty-one from other countries. The number from USA and Canada might well have been higher but for the gratuitous republieation of our letters in the advertising paper Dateline in Science of March 6, which I suppose is widely distributed among pharmacologists and others with an interest in prostaglandins. In any case, Letters to the Editor may possibly attract fewer requests than main articles.

In the meantime, requests for the original article continue to come in and must now number more than a thousand. All are from biologists although the articlo was written for non-biologists. It seems that I much underestimated its popularity, even if one allows that the number of spurious requests was much greater than the forty-two suggested by the "experiment" so far. Even this number is big enough to make me think I should add at the end of my next paper "Reprint requests by personal letter will be met while supplies last". The alternative would be to ignore the lot, except for those from places where the journal might be unavailable.

Yours sincerely,

$$
\text { V. R. PICKLes }
$$

University College,

Cardiff.
Sin, - We shared Professor Pickles's experience of receiving remarkably few reprint requests to our spoof letter (Nature, February 14, 1970). So far, there have been five or six from Europe, two from the United States and assorted requests to know the result of the experiment or to have a reprint, while pointing out that they had read the letter. Perhaps people in the latter category acquire all of Nature by reprint request rather than paying $4 s$ weekly. An interesting request, and one which we find not uncommon, is for the wrong reprint. In this case we were asked for a paper in Biochemical Journal, and we can only surmise that an unfortunate secretary has slipped a line on a print-out and sent the wrong request to hundreds of authors.

We agree that republication in Dateline in Science did our cause no good and are sorry that what we regarded as a delicate flower which would take a month or two to bear fruit had to be pulled up by its roots in an early stage to fill a spare column and receive a withering blast of publicity.

But perhaps we are pessimistic about the all-rounder. Perhaps child psychiatrists are interested in the development of the Red Sea.

It has occurred to us that the words "Plate" and "Red" in a recent paper ${ }^{1}$ may afford us a chance to catch the haematologists. Wo are only sorry now that we did not make the title "Plate Tectonics of the Red Sea; an Embryo Ocean".

$$
\text { Yours sincerely, }
$$$$
\text { D. Davies }
$$

MIT E-34,

42 Carleton Street,

Cambridge, Massachusetts 02142.

\section{P. McKenzie}

Department of Geodesy and Geophysics,

Maddingley Road,

Cambridge, England.

\section{J. S. TURNER}

Department of Applied Mathematics and

Theoretical Physics,

Silver Street,

Cambridge, England.

${ }^{1}$ McKenzie, D. P., Davies, D., and Molner, P., Nature, 226, 243 (1970).

\section{Are More Airports Necessary?}

SIR,-A recent editorial comment (Nature, April 25, $1970)$ suggests that the advert of the 300 m.p.h. hovertrain "may be the signal to banish the new airport once and for all from the heavily populated areas around London". When the full implications of high-spoed surface transport are taken into account we may be able to enlarge the point with economy of words by stopping at the phrase "once and for all".

Let us first considor the effects of a rapid-transit line connecting the airports of Gatwick, Heathrow, Birming. ham, Manchester, Prestwick, Abbotsinch and Edinburgh, with the additional assumption that these airports (and, perhaps, other convenient stations on the high-spood spine) would be connected to city centres by intermediate speed (say 100 m.p.h. train) collecting links.

The total length of the main line (which could follow existing motorway routes for much of its length) would be about 480 miles, corresponding to a non-stop journey time of about $1.75 \mathrm{~h}$ from one end to the other. Given a peak acceleration of $0 \cdot 1 \mathrm{~g}$, total acceleration time from a standing start would be about $3 \mathrm{~min}$, and each 2 -min stop would therefore add about $5 \mathrm{~min}$ to the journey. If 